\title{
PENERBITAN JURNAL ILMIAH UNTUK MENINGKATKAN KUALITAS SUMBER DAYA MANUSIA
}

\author{
B.P. Sitepu*
}

\begin{abstract}
Scientific journal is one of the periodical publications intended to widely disseminate research findings useful for research and academic communities. Articles published in the journal tend to be highly technical, representing the latest theoretical research and experimental results in the field of science, technolgy, or arts covered by the journal. Articles in the journal can be used as references and inspire researchers and scholars to do further researh. The quantity and quality of journals in a country can indicate the quality of the human resource and development of science, technology, and arts in the country. Based on the available data, the quantity and the quality of journal in Indonesia are still unsatisfactory. This article discusses some problems in managing journal and provides a number of recommendation which are useful for those publishing a journal.
\end{abstract}

Keywords: scientific journal, publication

\begin{abstract}
Abstrak
Jurnal ilmiah yang merupakan penerbitan berkala dimaksudkan untuk menyebarluaskan hasil-hasil penelitian di kalangan masyarakat akademisi dan peneliti. Naskah yang dimuat di jurnal bersifat sangat teknis, menggunakan teori penelitian dan hasil penelitian yang mutakhir dalam bidang ilmu pengetahuan, teknologi, dan seni yang menjadi liputan jurnal itu. Laporan penelitian dalam jurnal bermanfaat bagi peneliti dan akademisi sebagai rujukan dan bahan kajian. Jumlah dan mutu jurnal di suatu negara dapat dijadikan salah satu indikator kemajuan ilmu pengetahuan, dan seni di negeri itu. Berdasarkan data yang ada, jumlah dan mutu jurnal di Indonesia masih kurang memadai. Tulisan ini mengkaji berbagai masalah dalam pengembangan jurnal serta memberikan sejumlah saran bagaimana mengembangkan penerbitan jurnal di Indonesia.
\end{abstract}

Kata-kata kunci: jurnal ilmiah, publikasi

\section{PENDAHULUAN}

Di era informasi dan globalisasi abad ke 21 ini semakin terasa ilmu pengetahuan dan teknologi maju begitu pesat serta persaingan dalam mengejar kemajuan antar bangsa/negara semakin ketat. Tingkat peradaban suatu bangsa dewasa ini cenderung diukur dari kemajuan ilmu pengetahuan dan teknologi yang dihasilkan serta diterapkan dalam kehidupan individu, masyarakat, dan bangsa itu. Negara-negara maju semakin berpacu menghasilkan ilmu pengetahuan dan teknologi serta menjadikannya sebagai barang komoditas. Sementara itu masih banyak juga bangsa yang kemajuannya masih pada tingkat pengguna ilmu pengetahuan, teknologi, dan seni (ipteks) yang dihasilkan negara yang lebih maju. Bangsa yang memiliki ketergantungan pada bangsa lain tentu

*Dosen Pascasarjana Teknologi Pendidikan UNJ mengalami berbagai tantangan dan masalah dalam memajukan dan meningkatkan peradabannya secara mandiri.

Lembaga pendidikan diyakini sebagai suatu wadah yang dapat menghasilkan sumber daya manusia bermutu melalui proses pembelajaran yang dapat memberikan dan mengembangkan pengetahuan dan keterampilan serta membentuk kepribadian. Materi dan proses pendidikan juga dapat meningkatkan kemampuan intelektual peserta didik sehingga mampu berpikir kritis, kreatif, dan inovatif dalam menanggapi berbagai persoalan dalam hidupnya. Dengan demikian keluaran lembaga pendidikan diharapkan dapat secara cerdas dan bermoral/beradab membangun dirinya sendiri serta lingkungannya.

Fungsi lembaga pendidikan di tingkat pendidikan dasar dan menengah lebih banyak diarahkan pada 
penguasaan ipteks sesuai dengan tingkatannya. Peserta didik di tingkat pendidikan dasar lebih banyak belajar untuk diterapkan dalam kehidupan. Sungguhpun terdapat sejumlah peserta didik yang dapat mengembangkan atau menghasilkan temuan baru, tetapi pada hakikatnya bukan merupakan fungsi pokok pendidikan dasar dan menengah.

Dengan Tri Dharma yang dimilikinya, perguruan tinggi berfungsi membelajarkan, melakukan penelitian, dan mengabdi kepada masyarakat. Tri Dharma itu menunjukkan bahwa setiap perguruan tinggi tidak semata-mata berkonsentrasi pada membelajarkan saja (teaching), tetapi juga melakukan penelitian (research), serta melakukan kegiatan pengabdian kepada masyarakat sehingga tidak merupakan menara gading yang terpisah dari kehidupan dan kepentingan masyarakat. Dengan demikian, selain sebagai sumber belajar, perguruan tinggi berfungsi menghasilkan berbagai ilmu pengetahuan, teknologi, dan seni yang baru melalui kajian dan penelitian yang dilakukannya secara terencana dan terus menerus. Perguruan tinggi tidak hanya berfungsi sebagai pengguna tetapi juga penghasil ipteks. Hasil-hasil penelitian mahasiswa untuk keperluan penulisan skripsi, thesis, atau disertasi serta yang dilakukan oleh lembaga penelitian (Lemlit) perguruan tinggi diharapakan memberikan kontribusi dalam memperkaya khasanah ipteks dan bukan hanya sekedar untuk memenuhi persyaratan akademis semata.

Pengembangan ipteks bukan hanya tugas perguruan tinggi, tetapi juga merupakan kewajiban lembaga/badan penelitian lain yang dimiliki pemerintah atau swasta. Di Indonesia sendiri terdapat lembaga/ badan penelitian yang menghasilkan berbagai temuan baru sungguhpun kurang dikenal secara nasional dan internasional karena kurang dipublikasikan. Hasil-hasil penelitian Indonesia yang telah memiliki hak paten secara nasional dan internasional belum banyak serta kurang dipublikasikan.

Uraian yang dikemukakan baru berkaitan dan berfokus pada pendidikan formal, sedangkan dalam sistem pendidikan nasional dikenal jalur pendidikan formal, nonformal, dan informal. Permasalah pendidikan tidak hanya dibebankan pada lembaga-lembaga pendidikan formal,tetapi juga menjadi tugas dan tanggung jawab jalur pendidikan nonformal dan informal. Untuk meningkatkan pemerataan kesempatan memperoleh pendidikan, misalnya, pendidikan nonformal menyelenggarakan program paket $\mathrm{A}, \mathrm{B}$, dan $C$ serta berbagai kursus keterampilan dan kesenian. Program keaksaraan untuk orang dewasa pada umumnya dilakukan melalui pendidikan nonformal.
Peranan pendidikan nonformal semakin penting dan stategis khususnya di kala pendidikan formal menghadapi berbagai keterbatasan dan kendala meratakan kesempatan memperoleh pendidikan. Tumbuh dan berkembangnya lembaga-lembaga pendidikan nonformal merupakan gejala keterbatasan pendidikan formal baik dari segi jumlah, mutu, atau relevansi. Akan tetapi perlu segera dicatat bahwa pendidikan jalur formal bukan merupakan pelengkap jalur pendidikan formal. Tugas dan fungsi pendidikan nonformal adalah setara dengan pendidikan formal yang berarti bahwa mutu proses dan hasil pendidikan jalur pendidikan non formal adalah setara dengan pendidikan formal. Hal ini jelas terbaca dalam Pasal 26 UndangUndang tentang Sistem Pendidikan Nasional Tahun 2003 dan mengisyaratkan bahwa lulusan pendidikan nonformal dimungkin pindah ke jalur pendidikan formal pada tingkat pendidikan tertentu dan sebaliknya.

Tugas, fungsi, dan tujuan pendidikan nonformal menuntut penyelenggaraan pendidikan nonformal juga harus memiliki standar yang menjamin kesetaraan proses dan hasilnya dengan pendidikan formal. Walaupun sampai sekarang ini pendidikan nonformal belum memiliki delapan standar seperti di pendidikan formal, pada gilirannya nanti standar yang sejenis perlu juga dirumuskan untuk pendidikan nonformal. Dengan demikian, lembaga pendidikan formal benar-benar dapat dijadikan sumber belajar yang bermutu bagi peserta didiknya dan oleh karena itu perlu dikelola oleh pendidik dan tenaga kependidikan yang profesional. Untuk itu, status dan kualifikasi tenaga pendidik dan kependidikan nonformal seharusnya juga setara dengan pendidikan formal. Sebagai contoh, untuk menjadi pendidik profesional dituntut kemampuan profesional, kemampuan pedagogik, kemampuan sosial dan kepribadian yang dibuktikan sengan sertifikasi pendidik. Salah satu prinsip profesionalitas pendidik menurut Pasal 7 UU No. 14 Tahun 2005 tentang Guru dan Dosen ialah memiliki kesempatan untuk mengembangkan keprofesionalan secara berkelanjutan dengan belajar sepanjang hayat .

Belajar sepanjang hayat bagi seorang pendidik berarti tidak hanya menjadi pengguna tetapi juga penghasil ipteks, khususnya di bidang ilmu atau keterampilan yang ditekuninya. Untuk dapat menjadi penghasil ipteks diperlukan berbagai kegiatan penelitian yang hasilnya dipublikasikan dan diakui secara nasional dan internasional. Pendidik di jalur pendidikan formal dan nonformal memiliki kewajiban yang sama menghasilkan atau mengembangkan ipteks melalui penelitian di bidang keahliannya. Banyak masalah pendidikan nonformal yang perlu diteliti dan dipecahkan 
serta tidak mustahil melalui penelitian itu ditemukan metode belajar membelajarkan yang unik dan baru.

Laporan penelitian biasanya dipublikasikan melalui media tertentu yang disebut jurnal ilmiah dalam bentuk cetak atau elektronik. Jumlah, mutu, serta peredaran jurnal ilmiah dapat dijadikan salah satu indikator kemajuan penelitian pada khususnya dan ipteks pada umumnya di suatu negara. Bahkan keadaan penerbitan ilmiah di suatu negara dapat juga dijadikan salah satu indikator mutu sumber manusia di negara itu. Bagaimana keadaan dan perkembangan jurnal ilmiah di Indonesia serta hambatan-hambatan yang dihadapi menjadi bahasan dalam tulisan ini.

\section{JURNAL ILMIAH DI INDONESIA}

Jurnal ilmiah merupakan jenis terbitan berkala tercetak berisi laporan penelitian dalam bentuk artikel/ makalah di bidang disiplin ilmu tertentu, diterbitkan dan diedarkan di kalangan ilmuwan/akademisi/cendikiawan. Jurnal ilmiah berfungsi sebagai media komunikasi yang dapat dijadikan sebagai rujukan dalam melakukan penelitian atau karya ilmiah lainnya. Lazimnya jurnal ilmiah diterbitkan oleh asosiasi profesi, lembaga riset, universitas maupun penerbit, dengan lingkup yang cukup spesifik. Di lihat dari isi, jumlah tiras, dan penyebarannya, jurnal dapat pula dikategorikan sebagai jurnal nasional dan jurnal internasional. Persyaratan untuk masing-masing jurnal tentu berbeda terutama dilihat dari bobot ilmiah, lingkup, dan bahasanya. Oleh karena jurnal ilmiah memuat laporan hasil penelitian, dan manfaat jurnal itu sangat tergantung pada mutu penelitian yang dilakukan dan dilaporkan.

Dilihat dari mutu isi, keteraturan terbit, jumlah tiras, peredaraan dan pengelolannya, jurnal dikelompokkan menjadi jurnal terakreditasi dan jurnal tidak terakreditasi. Jurnal terakreditasi dikategorikan ke dalam peringkat $A, B$, dan $C$. Akreditasi dilakukan oleh lembaga/instansi yang diberi wewenang untuk itu , misalnya, untuk jurnal pendidikan tinggi akreditasi dilakukan oleh Direktorat Penelitian dan Pengabdian kepada Masyarakat, Direktorat Jenderal Pendidikan Tinggi (DP2M DIKTI). Sedangkan jurnal untuk kalangan di luar pendidikan tinggi diakreditasi oleh Lembaga IImu Pengetahuan Indonesia (LIPI).

Sebelum diakreditasi setiap jurnal didaftarkan di LIPI untuk mendapatka ISSN (International Standard Serial Number).

Di samping dilakukan oleh lembaga/badan penelitian serta beberapa organisasi profesi, penerbitan jurnal dilakukan oleh perguruan tinggi. Besarnya minat perguruan tinggi menerbitkan jurnal berkaitan dengan persyaratan akreditasi dan kenaikan pangkat/jabatan dosen. Dilihat dari bidang ilmu dan peringkat akreditasinya, jumlah jurnal yang diakreditasi oleh DP2M DIKTI untuk periode 2007-2010 adalah seperti tertera pada tabel berikut.
Tabel 1. Jumlah Jurnal yang Terakreditasi oleh Ditjen Dikti 2007 sampai 2010

\begin{tabular}{|c|c|c|c|c|c|}
\hline \multirow{2}{*}{ No. } & \multirow{2}{*}{ Bidang Ilmu } & \multicolumn{3}{|c|}{ Akreditasi } & \multirow{2}{*}{$\begin{array}{l}\text { Jum- } \\
\text { Lah }\end{array}$} \\
\hline & & A & B & $\mathrm{C}$ & \\
\hline 1 & Agama & 2 & 10 & 5 & 17 \\
\hline 2 & Ekonomi & 1 & 15 & 25 & 41 \\
\hline 3 & Hukum & 0 & 8 & 9 & 17 \\
\hline 4 & Pendidikan & 1 & 13 & 7 & 21 \\
\hline 5 & Kesehatan & 5 & 12 & 11 & 28 \\
\hline 6 & MIPA & 1 & 8 & 11 & 20 \\
\hline 7 & Pertanian & 0 & 10 & 14 & 24 \\
\hline 8 & Psikologi & 0 & 0 & 2 & 2 \\
\hline 9 & Rekayasa & 1 & 17 & 25 & 43 \\
\hline 10 & $\begin{array}{l}\text { Sastra dan } \\
\text { Filsafat }\end{array}$ & 0 & 5 & 2 & 7 \\
\hline 11 & Seni & 0 & 0 & 1 & 1 \\
\hline 12 & $\begin{array}{l}\text { Sosial dan } \\
\text { Humaniora }\end{array}$ & 0 & 5 & 11 & 16 \\
\hline \multicolumn{2}{|c|}{ JUMLAH } & 11 & 103 & 119 & 233 \\
\hline
\end{tabular}

Data dalam Tabel 1 menunjukkan bahwa jumlah jurnal yang terakreditasi masih sedikit dibandingkan dengan jumlah lembaga yang melakukan penelitian yang secara keseluruhan berjumlah 622 dengan rincian sebagai berikut.

Tabel 2. Jumlah Lembaga yang Melakukan Penelitian

\begin{tabular}{|r|l|r||}
\hline No & \multicolumn{1}{|c|}{ Lembaga } & Jmh \\
\hline 1 & Perguruan Tinggi Negeri & 114 \\
\hline 2 & Perguruan Tinggi Swasta & 301 \\
\hline 4 & Badan Usaha Milik Negara & 8 \\
\hline 5 & Badan Usaha Milik Swasta & 8 \\
\hline 6 & Lembaga Penelitian Departemen & 76 \\
\hline 7 & $\begin{array}{l}\text { Lembaga Penelitian } \\
\text { Nondepartemen }\end{array}$ \\
\hline 8 & $\begin{array}{l}\text { Lembaga Penelitian Pembangunan } \\
\text { Daerah }\end{array}$ & 24 \\
\hline & Jumlah & 622 \\
\hline
\end{tabular}

Sumber: Ketua Dewan Riset Nasional dalam Kompas 13 Desember 
Data dalam Tabel 2 menunjukkan antara lain, penelitian yang terbanyak dilakukan oleh perguruan paling besar 415 atau $66,7 \%$. Akan tetapi angka tersebut termasuk kecil $(15,5 \%)$, dilihat dari jumlah keseluruhan perguruan tinggi negeri dan swasta yang berjumlah 2.680 pada tahun 2008 .

Dilihat dari mutunya, berdasarkan kriteria akreditasi oleh Ditjendikti, lebih dari sebagian $(51,1 \%)$ terakreditasi $\mathrm{C}$, kurang dari sebagaian $(44,2 \%)$ terakreditasi $B$, dan sangat sedikit sekali $(4,7 \%)$ terakreditasi A. Data tersebut berlaku pada periode 2007 -2010. Data hasil penilaian Ditjendikti periode II 2010 atas jurnal yang diterbitkan oleh perguruan tinggi, lembaga penelitian, dan organisasi profesi menunjukkan, hanya ada 2 jurnal terakreditasi A (sangat baik) dan 26 jurnal terakreditasi B. Sementara itu 46 jurnal tidak terakreditasi walaupun beberapa di antaranya dari perguruan tinggi ternama. (Kompas, 13 Desember 2010). Hasil akreditasi tahun 2010 itu menunjukkan penurunan jumlah jurnal yang terakreditasi dan dan juga memberikan indikasi menurunnya mutu jurnal yang diterbitkan.

Di lain pihak, Lembaga IImu Pengetahuan Indonesia (LIPI) juga melakukan akreditasi terhadap jurnal yang isinya di luar pendidikan tinggi. Hasil akreditasi LIPI adalah seperti tertera dalam tabel 3 berikut.

Tabel 4. Jurnal Terakreditasi Menurut LIPI (2010)

\begin{tabular}{|c|c|c|c|c|c|}
\hline \multirow{2}{*}{ No. } & \multirow{2}{*}{ Bidang IImu } & \multicolumn{3}{|c|}{ Akreditasi } & \multirow{2}{*}{$\begin{array}{c}\text { Juml } \\
\text { ah }\end{array}$} \\
\hline & & A & B & C & \\
\hline 1 & Sejarah dan Arkeologi & - & 2 & 1 & 3 \\
\hline 2 & Standarisasi & - & 1 & - & 1 \\
\hline 3 & $\begin{array}{l}\text { Ilmu Politik dan } \\
\text { Kebijakan }\end{array}$ & 1 & 1 & 3 & 5 \\
\hline 4 & $\begin{array}{l}\text { Pertanian, } \\
\text { Perkebunan (The dan } \\
\text { Kina) }\end{array}$ & - & 1 & - & 1 \\
\hline 5 & Kebijakan Kehutanan & - & 2 & - & 2 \\
\hline 6 & Rekayasa dan Teknik & 6 & 17 & 9 & 32 \\
\hline 7 & $\begin{array}{l}\text { Teknologi Informasi } \\
\text { dan Komunikasi }\end{array}$ & & 2 & 2 & 4 \\
\hline 8 & Biologi & 3 & 1 & - & 4 \\
\hline 9 & $\begin{array}{l}\text { Biologi (Fauna } \\
\text { Tropika) }\end{array}$ & - & 1 & - & 1 \\
\hline
\end{tabular}

Tabel 4. Jurnal Terakreditasi Menurut LIPI (2010)

\begin{tabular}{|c|c|c|c|c|c|}
\hline \multirow{2}{*}{ No. } & \multirow{2}{*}{ Bidang IImu } & \multicolumn{3}{|c|}{ Akreditasi } & \multirow{2}{*}{$\begin{array}{l}\text { Juml } \\
\text { ah }\end{array}$} \\
\hline & & A & $B$ & C & \\
\hline 10 & $\begin{array}{l}\text { Kedokteran dan } \\
\text { Kesehatan }\end{array}$ & - & 3 & 1 & 4 \\
\hline 11 & $\begin{array}{l}\text { Pertanian, } \\
\text { Kedokteran Hewan, } \\
\text { dan Lingkungan }\end{array}$ & 5 & 18 & 5 & 28 \\
\hline 12 & $\begin{array}{l}\text { Pertanian, } \\
\text { Kedokteran, dan } \\
\text { Hewan }\end{array}$ & 2 & 1 & 0 & 3 \\
\hline 13 & $\begin{array}{l}\text { Perdagangan, } \\
\text { Manajemen } \\
\text { Pariwisata, dan Jasa }\end{array}$ & - & 2 & 1 & 3 \\
\hline 14 & $\begin{array}{l}\text { Perdagangan, } \\
\text { Manajemen, } \\
\text { Pariwisata }\end{array}$ & & 1 & - & 1 \\
\hline 15 & Ekonomi & 2 & 3 & 2 & 7 \\
\hline 16 & Kimia dan Fisika & - & 1 & - & 1 \\
\hline 17 & $\begin{array}{l}\text { Umum, Ilmu Politik } \\
\text { dan Kebijakan }\end{array}$ & - & 1 & 0 & 1 \\
\hline 18 & Kebumian & 2 & 9 & 6 & 17 \\
\hline 19 & $\begin{array}{l}\text { Kebumian dan } \\
\text { Antariksa }\end{array}$ & - & 1 & 0 & 1 \\
\hline 20 & $\begin{array}{l}\text { Kebumian dan } \\
\text { Penginderaan Jauh }\end{array}$ & - & 1 & - & 1 \\
\hline 21 & $\begin{array}{l}\text { Agama, Filosofi, dan } \\
\text { Sistem }\end{array}$ & 1 & 1 & - & 2 \\
\hline 22 & $\begin{array}{l}\text { Studi } \\
\text { Kemasyarakatan }\end{array}$ & 2 & 2 & 1 & 5 \\
\hline 23 & $\begin{array}{l}\text { Jurnalistik, } \\
\text { Keperpusatakaan, } \\
\text { dan Kurator }\end{array}$ & - & - & 2 & 2 \\
\hline 24 & $\begin{array}{l}\text { Arsitektur, Gedung, } \\
\text { Lingkungan Kota }\end{array}$ & - & - & 1 & 1 \\
\hline 25 & Pendidikan & - & 1 & 1 & 2 \\
\hline 26 & IImu Sosial & 1 & - & - & 1 \\
\hline 27 & Umum & - & - & 1 & 1 \\
\hline & Jumlah & 25 & 73 & 36 & 134 \\
\hline
\end{tabular}

Hasi akreditasi LIPI tersebut menunjukkan antara lain bahwa jumlah jurnal yang terakreditasi lebih sedikit dari yang diakreditasi Ditjendikti (2007 - 2010) dan jumlah jurnal yang terakreditasi $A$ juga hanya sedikit banyak $(18,7 \%)$. Dilihat dari isinya, jurnal yang diakreditasi itu dapat dikelompokkan ke dalam 27 spesialisasi, yang sungguhpun bervariasi tapi nampaknya masih dapat dikembangkan lagi.

Data hasil akreditasi jurnal yang dilakukan oleh Ditjendikti dan LIPI menunjukkan rendahnya mutu jurnal yang diterbitkan dan yang tergolong sangat baik (A) sangat sedikit. Keadaan ini terjadi karena berbagai hambatan yang dihadapi lembaga dan pengelola penerbitan jurnal.

\section{TANTANGAN DALAM PENERBITAN JURNAL}

Hambatan dalam penerbitan jurnal berkaitan dengan (a) pengadaan naskah, (2) pengolahan naskah, dan (b) pendanaan pengelolaan penerbitan. Dalam penerbitan berkala seperti jurnal persyaratan utama tersedianya naskah yang memenuhi persyaratan dilihat dari isi dan jumlahnya. Isi naskah harus sesuai dengan ciri jurnal tersebut serta panjang naskah layak untuk diterbitkan (tdak terlalu pendek dan tidak terlalu panjang). Isi naskah merupakan laporan penelitian yang relevan dan masalah penelitian serta hasilnya adalah dapat dipertanggungjawabkan secara ilmiah, baru, bermanfaat, serta bersekala nasional atau internasional. Kelayakan isi naskah dinilai oleh mitra bestari di luar lembaga yang menerbitkan jurnal.

Tidak dapat atau terlambatnya penerbitan jurnal biasanya terutama dikarenakan kurangnya naskah yang diterima pengeloa jurnal atau banyak naskah tetapi tidak memenuhi syarat. Kurangnya naskah terkait dengan 
kurangnya penelitian yang dilakukan karena kesibukan atau rendahnya minat atau kemampuan meneliti. Kemungkinan lain ialah hasil penelitian dianggap hanya untuk kalangan terbatas serta bukan untuk dipublikasikan.

Sedangkan naskah yang tidak memenuhi syarat biasanya karena (a) isi tidak sesuai dengan bidang ilmu garapan jurnal, (b) isi tidak lengkap/tidak utuh, bahasanya sulit dipahami, (c) masalah yang diteliti merupakan perulangan dari penelitian-penelitian sebelumnya walaupun tempat dan waktunya berbeda, (d) masalah dan hasil penelitian bersekala lokal, dan (e) kurang dapat dimanfaatkan untuk keperluan teoretis maupun praktis.

Pengelolaan penerbitan jurnal merupakan masalah lain yang juga menjadi hambatan dalam penerbitan jurnal secara teratur dan tepat waktu. Pada umumnya penerbitan jurnal ditangani secara sambilan (Kompas, 11 Desember 2010) bukan oleh tenaga khusus dan profesional. Dalam kenyataannya sering dialami kesulitan menemukan mitra bestari yang sesuai dan memiliki waktu yang cukup mengkaji naskah secara teliti. Masalah lain ialah kurangnya tenaga penyunting naskah yang terampil. Oleh karena terbit berkala, pada umumnya pengelola jurnal bekerja paruh waktu, sedangkan tugas pokoknya adalah di tempat lain. Peminat jurnal adalah kalangan tertentu dan jumlahnya tidak banyak, maka pemasaran jurnal secara komersial tidak menguntungkan sehingga biasanya dana untuk pengelolaan jurnal juga minim.

Khusus untuk penerbitan Jurnal IImiah VISI PTKPNF ini, masalah yang dihadapi tidak jauh berbeda dengan pengalaman penerbitan jurnal lainnya. Dari segi pembiayaan tidak menghadapi hambatan yang bearti tetapi memperoleh naskah yang memenuh syarat merupakan tantangan tersendiri karena bidang garapan jurnal ini sangat spesifik sedangkan jumlah peneliti dan penelitian di bidang itu sangat terbatas.

Dalam kenyataannya, pengadaan naskah sering menghadapi kendala karena antara lain; (a) kurangnya penelitian yang berkaitan dengan tema jurnal, (b) masalah yang diteliti terlalu bersifat spesifik dan kasus sehingga hasilnya hanya berlaku untuk tempat dan waku tertentu saja, dan (c) peneliti terlalu sibuk untuk menuliskan laporan penelitiannya dalam bentuk naskah jurnal. Sebagai ilustrasi, Jurnal IImiah VISI yang diterbitkan oleh Direktorat PTKPNF bekerja sama dengan FIP UNJ ini memiliki tema tentang pendidik dan tenaga kependidikan pendidikan nonformal. Jurnal ini diharapkan memuat naskah-naskah.

\section{PENUTUP}

Jurnal sangat diperlukan sebagai media untuk menyebarluaskan hasil-hasil penelitian yang sangat diperlukan dalam pengembangan ipteks. Akan tetapi di Indonesia perkembangan penerbitan jurnal yang terakreditasi masih tergolong lambat. Untuk meningkatkan jumlah dan mutu jurnal sehingga terakreditasi di tingkat nasional dan internasional perlu diberikan kemudahan-kemudahan kepada lembaga-lembaga penelitian untuk melakukan penelitian yang bermutu dan keterampilan pengelola jurnal perlu ditingkatkan melalui berbagai pelatihan.

\section{DAFTAR PUSTAKA}

Himpunan perundang-undangan Republik Indonesia tentang sistem pendidikan nasional. (2008). Jakarta: Nuansa Aulia

Hames, I. (2007). Peer review and manuscript management in scientific journals. Maden, Oxford, Victoria : Blackwell Publishing.

Badan Penelitian dan Pengembangan Departemen Pendidikan Nasional. (2008). Buku saku : Ikhtisar data pendidikan nasional Tahun 2007/ 2008. Jakarta : Departemen Pendidikan Nasional
Rencana Strategi (Renstra) Kementerian Pendidikan Nasional 2010 - 2014. Diakses pada tanggal 17 Desember 2010 dari http://kemdiknas.go.id/ media-publik/rencana-strategis/rencanastrategi-(renstra)-kementerian-pendidikannasional-2010-2014.aspx.

Undang-undang Republik Indonesia no 14 tahun 2005 tentang guru dan dosen. (2006). Jakarta: Eka Jaya 